\title{
FACTORS AFFECTING THE SUCCESS OF MULTI DRUG RESISTANCE (MDR-TB) TUBERCULOSIS TREATMENT IN RESIDENTIAL SURAKARTA
}

\author{
Elisabeth Ria Widyasrini ${ }^{1,2}$, Ari N Probandari3), Reviono4) \\ 1)Public Health Center, Klaten \\ 2)Masters Program in Family Medicine, Sebelas Maret University \\ 3)Faculty of Medicine, Sebelas Maret University \\ 4)Department of Pulmonology and Respiratory Medicine, Dr. Moewardi, \\ Surakarta
}

\begin{abstract}
Background: Tuberculosis (TB) is a global public health concern. The new challenge in TB control is the development of TB multi drug resistance (MDRTB). Indonesia ranks 8th highest in the incidence of MDR-TB with 8,900 MDR-TB cases in 2004. A case was defined as MDR-TB if the Mycobacterium tuberculosis was resistant to rifampicin dan isoniazid. This study aimed to determine the factors affecting the success of multi drug resistance (MDR-TB) tuberculosis treatment.

Subjects and Method: This was an analytic observational study using case control design. The study was conducted at Dr. Moewardi Hospital, Surakarta, Central Java, Indonesia, in October 2014. The case population were MDR-TB patients visiting Dr. Moewardi Hospital for TB treatment from 2011 to October 2014. A sample of 84 TB cases consisting of 26 patients who dropped out, defaulted, or died, and 58 patients who successfully completed TB treatment, were selected for this study. The independent variables were sex, age, marital status, nutrional status, education, employment status, drug side effect, family support, and distance to health facility. The dependent variable was success of treatment. The data were collected by direct interview, questionnaire, and medical record. Logistic regression was employed for data analysis.

Results: Age $(\mathrm{OR}=0.93 ; 95 \% \mathrm{CI}=0.88$ to $0.97 ; \mathrm{p}=0.004)$ and drug side effect $(\mathrm{OR}=6.84 ; 95 \% \mathrm{CI}=2.50$ to $18.74 ; \mathrm{p}<0.001)$ affected the success of $\mathrm{TB}$ treatment and statistically significant. Sex $(\mathrm{OR}=0.66 ; 95 \% \mathrm{CI}=0.17$ to 2.58 ; $\mathrm{p}=0.556)$, education $(\mathrm{OR}=0.90 ; 95 \% \mathrm{CI}=0.52$ to $1.58 ; \mathrm{p}=0.724)$, employment status $(\mathrm{OR}=0.87 ; 95 \% \mathrm{CI}=0.59$ to $1.28 ; \mathrm{p}=0.485)$ affected the success of TB treatment but statistically not significant.
\end{abstract}

Conclusion: Success of TB treatment is affected by age and drug side effect.

Keywords: success of treatment, tuberculosis, multi drug resistance

Correspondence: Elisabeth Ria Widyasrini. Public Health Center, Klaten, Central Java. Email: lisabalkesmasklaten@gmail.com.

Mobile: +628990833108. 